\title{
Risk-oriented approach environmental safety of the devastated territories for urban development
}

\author{
Elena Voskresenskaya ${ }^{1, *}$, Lybov Vorona-Slivinskaya ${ }^{2}$ and Tatyana Ponomareva ${ }^{3}$ \\ ${ }^{1}$ Peter the Great St.Petersburg Polytechnic University, Polytechnicheskaya str., 29, 195251, St. \\ Petersburg, Russia \\ ${ }^{2}$ Saint Petersburg State University of Architecture and Civil Engineering, 2nd Krasnoarmeyskaya St., \\ 4, 190005, St. Petersburg, Russia \\ ${ }^{3}$ Admiral Makarov State University of Marine and Inland Shipping, Dvinskaya st., 5/7, 198035, Saint- \\ Petersburg, Russia
}

\begin{abstract}
The article considers the possibilities to improve the use of devastated territories of the Russian Federation, particularly of the Northwest Federal District and the Leningrad Oblast. The work provides data on monitoring the formation, usage and disposal of waste and outlines the range of environmental problems occurring due to exploitation of devastated territories. Measures of optimizing these territories, prospects for their implementation and related risks that may entail economic losses for urban development were determined in the article. This work reveals the important role of geoecological factors played in addressing the issues of preparing such areas for further building development. The study of characteristics and classification of devastated lands is of great importance for the rational planning of urban space. Successful rehabilitation of devastated lands enables their integration into the urban environment, the most effective usage and ensuring their social and economic potential growth for urban development.
\end{abstract}

\section{Introduction}

Today, there is a need to analyze the opportunities and risks for implementing mechanisms of using devastated territories. Yet it is worth mentioning that the key problems of the concept of sustainable development of Russia's cities are long-term planning of operational and economic activities for disposing of household and industrial waste at specialized landfills with minimizing the negative impact on population health and the environment, along with creation of ecological framework for the spatial organization of territories in the regions. Therefore, the chosen topic is definitely relevant.

The problem stays relevant while the efficient use of urban areas is impossible due to large land plots remaining devastated and non-rehabilitated. The main problem is inability to use urban areas efficiently, while large areas of cities remain non-rehabilitated and

\footnotetext{
* Corresponding author: elenvoskr@mail.ru
} 
devastated. Ignoring the devastated lands can result in economic losses for urban development.

The problems concerning the use of devastated territories were considered by such authors as: Voronin A.O., Gordienko I.I., Grechko V.V., Andreev S.V., Tkacheva I.V. [1-5]. The authors of the present article have studied certain problems of the legal and organizational-economic mechanism of using territories belonging to different types for urban development as well [6-9]. However, there has not been any targeted comprehensive study of land plots belonging to this category yet.

\section{Materials and Methods}

With the development of modern society, there has been a worldwide increase in the number of large and small cities, which can appear as an expansion of the urban area. Urbanization proceeds fast, which leads to occupying surrounding lands by a city that absorbs areas having certain economic functions (pasture lands, cottage settlements, forest areas, etc.). Severely disturbed devastated lands can also be situated within a city usually appearing due to industrial facilities. Unlike the past disorderly use of land, today much attention is being paid to the territory planning. This approach implies efficient use of land in order to meet all the needs of the population. Ignoring the devastated lands can result in economic losses for a city.

Classifications of devastated lands, principles and methods for their rehabilitation were developed in international practice. Devastated lands are firstly spatial entities that have arisen as a result of industrial activities (usually the mining industry, etc.), which caused serious disturbances or destruction of natural vegetation, soils, exposure of rocks and the formation of specific anthropogenic forms of relief (such as quarries, dumps, etc), and secondly the areas used for the storage of solid domestic waste. This term is associated with other definitions that are similar and consonant to it, for instance "disturbed land" or "degraded territories." Devastated territory is a special case of disturbed and degraded land, which is characterized by a very high rate of technogenic transformation. The article considers the problems of using the territories occupied with solid domestic waste.

\section{Results}

Devastated territories are represented in all industrially advanced countries of the world. The most vivid examples of devastated lands are the Bingham Canyon Mine in the USA; the Ekati Diamond Mine in Canada; diamond mine in Kimberley, South Africa (kimberlite pipe "Big Hole") and others. Russia is no exception. The largest and most complex devastated territories are located in large resource-extracting and industrial regions of the country, for example, in the Ural economic district ("Kapitalnaya-1" mine), Yakutia ("Mir" tube).

The study showed that the territory of Russia has a lot of officially registered landfills and dumps, which have accumulated a significant amount of waste belonging to various hazard classes.

The operation of some polygons is suspended due to numerous violation of maintenance and operation rules. The lack of sufficient facilities for the storage of solid domestic waste, the high cost of transporting waste to disposal sites, insufficient control of local authorities and self-management for the collection and disposal of waste, lead to the formation of illegal dumps, which often become infection centers that can be dangerous for both people and animals.

Illegal dumps obviously pose environmental and sanitary problems, since they cause major pollution of the environment. The pollution mainly occurs when harmful substances 
penetrate into underground and surface waters. Elimination of illegal dumps is the responsibility of local governments. The measures for elimination of such dumps are occasionally taken, but most of the dumps appear again at the same places, because the reason for their formation is unsatisfactory collection and disposal of waste.

\section{Discussion}

In order to maximize the effective use of turban territory and reduce the negative impact on urban environment, devastated lands, which are potentially available for developing public areas, improving the quality of urban areas and transport services, should be rehabilitated.

The problem of waste in St. Petersburg and the Leningrad Oblast has been among the priority problems for five years. The amount of waste per inhabitant of the city increases every year. Collection and utilization of wastes are among the most important problems of St. Petersburg and the Leningrad Oblast. This is due to the significant amount and diversity of the composition of the waste generated. The problem becomes worse due to lack of precise information on the amount and quality of waste generated. The economic situation in the country encourages small enterprises to work without strict reporting on waste, so the period of work can be short, but the waste has enough time to penetrate the environment. Some confusion with issuing licenses for the transportation of waste has led to illegal dumping.

Household and construction waste from St. Petersburg and the Leningrad Oblast are located on landfills and processed at two waste processing plants. There are 11 landfills, about 60 legal and 70 illegal dumps in the Leningrad Oblast for storing domestic, lowhazardous industrial and construction waste. The annual volume of received waste is about 5 million $\mathrm{m}^{3}$. In addition, on the territory of the region's enterprises there are 12 slurry storage tanks, storage facilities, dumps and fields, 33 sludge sites for municipal waste. The landfills of St. Petersburg are in satisfactory condition and under constant monitoring.

The waste of sewage treatment facilities of St. Petersburg is about 500 thousand tons per year. These waste contain heavy metals, so their placement and storage requires a special approach. Waste of urban sewage treatment facilities occupy 163.5 ha of urban area. New areas are required for their further disposal. Therefore, the problem of utilization of sludge requires immediate solution.

Table 1 shows the indicators characterizing the formation, use, neutralization and disposal of waste from the economic activities of organizations and households in the North-West Federal District in 2016 [11]. The table shows that only about $50 \%$ of waste from the total number of waste generated is used or neutralized in the Northwest Federal District (50.1\%), including St. Petersburg (47\%) and Leningrad Oblast (53.9\%).

At first glance, the volume of waste in the Leningrad Oblast is significantly less than the capacity of the landfills. However, according to preliminary estimates and taking into account St. Petersburg, which also removes its waste to the Leningrad Oblast, the landfills will be out of capacity for sorting and storing waste in a couple of years. Five objects within a 50kilometer radius of St. Petersburg are almost out of capability to receive waste, particularly because of the remaining life ending.

Toxic waste generated at the enterprises of St. Petersburg and the Leningrad Oblast is sent to the disposal and burial site at the "Krasny Bor" landfill. As the capabilities of the landfill are almost exhausted, the city and regional governments are solving the problem of creating a new enterprise for the processing and disposal of industrial toxic waste. The European Community takes an active part in this matter. 
Table 1. Formation, usage, neutralization and disposal of waste from economic activities of organizations and households in the North-Western Federal District, thousand tons.

\begin{tabular}{|l|c|c|c|}
\hline & $\begin{array}{l}\text { Formation of } \\
\text { toxic waste }\end{array}$ & $\begin{array}{l}\text { Usage and } \\
\text { neutralization of toxic } \\
\text { waste in enterprises }\end{array}$ & $\begin{array}{c}\text { Usage and neutralization } \\
\text { as a percentage of total } \\
\text { toxic waste generated }\end{array}$ \\
\hline $\begin{array}{l}\text { North-Western Federal } \\
\text { District }\end{array}$ & 21298.5 & 10662.3 & 50.1 \\
\hline $\begin{array}{l}\text { The Republic of } \\
\text { Karelia }\end{array}$ & 61.8 & 710.8 & 11.5 \\
\hline Komi Republic & 5377.7 & 2188.7 & 40.7 \\
\hline Arhangelsk Oblast & 382.4 & 64.0 & 16.7 \\
\hline $\begin{array}{l}\text { including the Nenets } \\
\text { Autonomous District }\end{array}$ & 17.9 & 2.1 & 11.8 \\
\hline Vologda Oblast & 7003.7 & 4233.2 & 60.4 \\
\hline Kaliningrad Oblast & 21.3 & 13.3 & 62.5 \\
\hline Leningrad Oblast & 3139.8 & 1693.7 & 53.9 \\
\hline Murmansk Oblast & 2070.5 & 120.1 & .54 .1 \\
\hline Novgorod Oblast & 1782.7 & 963.6 & 13.4 \\
\hline Pskov Oblast & 30.0 & 4.0 & 47.0 \\
\hline $\begin{array}{l}\text { The city of Saint- } \\
\text { Petersburg }\end{array}$ & 1428.5 & 670.8 & \\
\hline
\end{tabular}

The table shows that only about $50 \%$ of waste from the total number of waste generated is used or neutralized in the Northwest Federal District (50.1\%), including St. Petersburg (47\%) and Leningrad Oblast (53.9\%).

At first glance, the volume of waste in the Leningrad Oblast is significantly less than the capacity of the landfills. However, according to preliminary estimates and taking into account St. Petersburg, which also removes its waste to the Leningrad Oblast, the landfills will be out of capacity for sorting and storing waste in a couple of years. Five objects within a 50kilometer radius of St. Petersburg are almost out of capability to receive waste, particularly because of the remaining life ending. Toxic waste generated at the enterprises of St. Petersburg and the Leningrad Oblast is sent to the disposal and burial site at the "Krasny Bor" landfill. As the capabilities of the landfill are almost exhausted, the city and regional governments are solving the problem of creating a new enterprise for the processing and disposal of industrial toxic waste. The European Community takes an active part in this matter.

In accordance with program "Environmental Protection of the Leningrad Oblast" the landfill in the Podporozhsky District was put into operation in 2017, landfills in Kingisepp are being put into operation in 2018, and landfills in the Tosnensky and Vyborgsky Districts will be put into operation in 2020. By the end of 2018 waste sorting stations in Vsevolozhsk, Volkhov, Kingisepp, Slantsy and Priozersk districts will have been built and started.

\section{Conclusions}

In conclusion, it is worth noting that the terrain structure of the devastated territories is quite complicated, since in some cases a combination of different types of devastated land is observed, which can complicate the process of their further rehabilitation. All the surveyed territories are polluted with solid domestic waste, or in other words the devastated territories accumulate various garbage. According to the analysis, the following measures can be taken 
in order to reduce the negative impact of the devastated territories on the health of the population.

1. To carry out a comprehensive inventory reconciliation of unauthorized landfills that do not have the appropriate legal documents, with certification of their locations and elaboration of ways to eliminate them.

2. To reconstruct the landfills of solid domestic waste with the extension of their service life, to put new ones into operation, ensuring the storage of waste in accordance with technical and environmental standards.

3. To complete the design and construction of waste processing facilities on the territory of the Leningrad Oblast.

4. To increase the capacity and the number of enterprises for the collection, processing and utilization of waste, with the provision of separate collection, storage and processing in order to obtain secondary raw materials, fuel and energy.

5. To carry out reclamation of waste storage sites on the basis of creating an economic incentive system (pledge-return schemes, benefits, interest-free loans, etc.) for business entities.

6. To encourage crating a specialized waste processing branch in the territory, which will enable reducing the volumes of waste formation both in production (in the chemical industry, in the production of building materials, etc.) and in households, ensuring their environmentally safe storage, preventing land pollution and repairing disturbed lands.

7. The annual monitoring of the entry of heavy elements into the environment is especially important for understanding the rate of pollution. The solution of this issue is a priority among measures that allow reducing the risks caused by pollution coming from the devastated territories.

8. Successful rehabilitation of devastated lands will allow them to be integrated into the environment, to maximize the efficiency of their usage, ensuring the development of their social and economic potential. Therefore, an important issue of the using such lands for urban development should be considered in further researches.

\section{References}

1. A.O. Voronin, Predostavlenie zemel' naselennykh punktov dlya stroitel'stva khozyaystvennykh (2009)

2. I.I. Gordienko, Pravovoe regulirovanie predostavleniya zemel'nykh uchastkov dlya stroitel'stva (2010)

3. V.V. Grechko, Pravovoe regulirovanie predostavleniya zemel'nykh uchastkov dlya zhilishchnogo stroitel'stva iz zemel', nakhodyashchikhsya $v$ gosudarstvennoy $i$ munitsipal'noy sobstvennosti (2013)

4. S.V. Andreev, Zemel'nyy pravoporyadok v oblasti gradostroitel'stva (2007)

5. I.V. Tkacheva, Pravovoe regulirovanie predostavleniya dlya stroitel'stva zemel'nykh uchastkov v gorode Moskve (2008)

6. E. Voskresenskaya, V. Snetkov Alexander Tebryaev and Zokhidjon Askarov V 2017 MATEC Web of Conferences 10608055

7. E. Voskresenskaya, L. Vorona-Slivinskaya, A. Loiko, Web of Scholar 6(24)-7, 32-37 (2018) doi: 10.31435/rsglobal_wos/12062018/5800

8. E. Voskresenskaya, L. V. Vorona-Slivinskaya, E3S Web of Conferences 33, 03052 (2018) https://doi.org/10.1051/e3sconf/20183303052

9. P.K. Sun, L.Vorona-Slivinskaya, E. Voskresenskaya, IOP Conference Series: Earth and Environmental Science 90 (2017) https://doi.org/10.1088/1755-1315/90/1/012073 
10. E. Voskresenskaya, L. Vorona-Slivinskaya, A. Loiko, Web of Scholar 6(24)-7, 32-37 (2018) doi: 10.31435/rsglobal_wos/12062018/5800

11. Regiony Rossii, Sotsial'no-ekonomicheskie pokazatel R32 (2017) 